\title{
A rare association of central hypothyroidism and adrenal insufficiency in a boy with Williams-Beuren syndrome
}

\author{
Devi Dayal, MD, \\ Dinesh Giri, MD, \\ Senthil Senniappan, MD, PhD \\ Department of Paediatric Endocrino- \\ logy, Alder Hey Children's Hospital \\ NHS Trust, Liverpool, UK
}

Primary hypothyroidism related to morphological and volumetric abnormalities of the thyroid gland is one of the commonest of several endocrine dysfunctions in Williams-Beuren syndrome (WBS). We report a 10-month-old boy with WBS who presented with central hypothyroidism. During the neonatal period, he had prolonged jaundice, feeding difficulties and episodes of colic that continued during early infancy. Additionally, there was slowing of growth and mild developmental delay. He underwent surgical repair for supravalvular aortic stenosis at 6 months of age. An evaluation done to exclude cortisol deficiency before initiating levothyroxine lead to the detection of secondary adrenal insufficiency, unreported previously in WBS. In addition, insulin-like growth factor-1 (IGF-1) and IGF-binding protein-3 levels were low. This report of hypopituitarism in WBS indicates a need for complete evaluation of pituitary dysfunction in children with WBS.

Keywords: Williams-Beuren syndrome, Central hypothyroidism, Adrenal insufficiency, Hypopituitarism

\section{Introduction}

Williams-Beuren syndrome (WBS) is a rare multisystemic genetic disorder caused by a heterozygous microdeletion of chromosome $7 \mathrm{q} 11.23^{1)}$. The usual incidence is estimated to be 1 in $1 / 7,500$ to $1 / 20,000$ live births ${ }^{2,3)}$. The characteristic features of WBS include congenital heart disease, mainly supravalvular aortic stenosis (SVAS), mental retardation, short stature, facial dysmorphisms, and variable abnormalities in different systems such as genitourinary, endocrinological, ophthalmological, and skeletal systems ${ }^{3,4)}$. Common endocrine problems reported in WBS are short stature, pubertal disorders, hypothyroidism and hypercalcemia ${ }^{4}$. Recent reports suggest the occurrence of additional endocrinopathies such as growth hormone deficiency, dyslipidemia, glucose intolerance, reduction in bone mineral status and impaired bone metabolism in these patients ${ }^{5-7)}$. These reports point to a need for close monitoring of endocrine dysfunction in patients with WBS to detect and treat any known or new abnormalities in a timely fashion ${ }^{5-7)}$. Thyroid dysfunction occurs in approximately $30 \%$ of patients with WBS and is characterized by the presence of thyroid gland abnormalities, particularly hypoplasia in a majority of the patients ${ }^{4,8-10)}$. All the patients reported till now had primary hypothyroidism. We recently found new abnormalities of thyroid and adrenal function in a child with WBS. The rarity of occurrence prompted us to report these findings.

\section{Case report}

A 10-month-old boy diagnosed as WBS was referred for evaluation of the endocrine function. The baby was born at term by an elective lower segment caesarean section due 
to a tapering of his intrauterine growth. The birth weight was $2.7 \mathrm{~kg}(-1.84$ standard deviation score [SDS]). Neonatal problems included prolonged jaundice, and feeding difficulties and extreme colic that continued into the early infancy. Chromosomal microarray analysis using International Standards for Cytogenomic Arrays' 8x60K Oligo array (Oxford Gene Technology, Oxford, UK) revealed an approximately 1.4$\mathrm{Mb}$ heterozygous loss of the long arm of chromosome 7, band $\mathrm{q} 11.23[\operatorname{arr}(\operatorname{hg} 19) 7 \mathrm{q} 11.23(72,766,312-74,142,342) \times 1]$. This microdeletion of chromosome 7q11.23 is consistent with WBS. The cardiac evaluation showed SVAS that was repaired at 6 months of age. There was no family history of an endocrine disorder. He had 3 healthy elder siblings. Parents observed slowing of growth and mild delay in achievement of milestones. The weight and length velocity were $4.4 \mathrm{~kg} / \mathrm{yr}$ and $16.2 \mathrm{~cm} /$ $\mathrm{yr}$, respectively. Head control and sitting without support were achieved at $4 \frac{1}{2}$ and 9 months, respectively.

On examination, his weight, length and head circumference were $6.4 \mathrm{~kg}$ (-3.74 SDS, standard growth chart, UK) (50th centile, Williams chart), $63.5 \mathrm{~cm}(-4.24$ SDS, standard growth chart, UK) (-2 SDS, Williams chart) and $45 \mathrm{~cm}(-0.75$, standard chart) (+2 SDS, Williams chart), respectively. He showed classical facial features of WBS. There was no goiter. Central adiposity, and small phallus (stretched penile length, $3.8 \mathrm{~cm}$ ) but normal testes (testicular volume, $1.0 \mathrm{~mL}$ by orchidometer) were noted. The systemic examination was otherwise unremarkable.

Investigations revealed normal hematological and biochemical parameters. Thyroid function tests evaluated twice showed a low free T4 of $0.63 \mathrm{ng} / \mathrm{dL}$ and $0.61 \mathrm{ng} / \mathrm{dL}$ (normal range, $0.70-1.94 \mathrm{ng} / \mathrm{dL}$ ) and an inappropriately normal TSH of $2.79 \mathrm{mIU} / \mathrm{L}$ and $2.04 \mathrm{mIU} / \mathrm{L}$ (normal range, $0.4-4.0$ $\mathrm{mIU} / \mathrm{L}$ ) suggestive of central hypothyroidism. The serum electrolytes and blood glucose were normal. A short synacthen stimulation test $(62.5 \mu \mathrm{g})$ showed a peak cortisol concentration of $13.1 \mu \mathrm{g} / \mathrm{dL}$ (normal stimulated concentration, $>18.0 \mu \mathrm{g} /$ dL). Adrenocorticotropin hormone (ACTH) level was not elevated $(23.0 \mathrm{pg} / \mathrm{mL}$ [normal range, $9-50 \mathrm{pg} / \mathrm{mL}$ ]) suggesting hypoadrenalism of pituitary etiology. 17-Hydroxyprogesterone and renin levels were $3 \mathrm{nmol} / \mathrm{L}$ (normal range, $0-6 \mathrm{nmol} / \mathrm{L}$ ) and $44 \mathrm{mU} / \mathrm{L}$ (normal range, $14.7-126.9 \mathrm{mU} / \mathrm{L}$ ), respectively. Insulin-like growth factor-1 (IGF-1) and IGF-binding protein-3 (IGFBP-3) levels were $<25.1 \mathrm{ng} / \mathrm{mL}$ (normal range, 30-152 $\mathrm{ng} / \mathrm{mL}$ ) and $831.2 \mathrm{ng} / \mathrm{mL}$ (normal range, 1,039-3,169 ng/ $\mathrm{mL}$ ), respectively suggesting a possibility of growth hormone deficiency or a poor nutritional status. Magnetic resonance imaging of the pituitary showed normal signal intensity and gland dimensions for age. Thyroid ultrasonography showed a eutopic gland with normal volume for age. The patient was initiated on hydrocortisone therapy followed by levothyroxine (50 $\mu \mathrm{g}$ once daily) replacement. At the last follow-up (age, 16 months), his thyroid (free T4, $1.25 \mathrm{ng} / \mathrm{dL} ; \mathrm{TSH}, 3.02 \mathrm{mIU} / \mathrm{L}$ ) and adrenal (morning serum cortisol, $7.8 \mu \mathrm{g} / \mathrm{dL}$; ACTH, 18.1 $\mathrm{pg} / \mathrm{mL}$ ) functions were normal. His weight and length were 9.2 $\mathrm{kg}(-1.55$ SDS, standard growth chart, UK) and $72.0 \mathrm{~cm}(-3.47$ SDS, standard growth chart, UK) respectively

\section{Discussion}

Endocrine dysfunction, especially hypothyroidism is commonly seen in patients with WBS ${ }^{4)}$. Primary hypothyroidism occurs in about one-third of all patients with $\mathrm{WBS}^{8-}$ ${ }^{10)}$. About $70 \%$ of the patients with hypothyroidism show morphological or volumetric abnormalities of the thyroid gland $^{8-10)}$. The major gland abnormality detected in these patients is hypoplasia ${ }^{8-10)}$. Unsurprisingly, therefore, most patients have subclinical hypothyroidism ${ }^{8-10}$. Central hypothyroidism has not been reported previously in patients with WBS. Ciccone et al. ${ }^{11)}$ recently reported a boy with WBS who had central hypothyroidism along with growth hormone deficiency but the patient was still undergoing investigations at the time of reporting. Additionally, thyroid gland hypoplasia was noted in that patient similar to several reports of thyroid gland abnormalities causing primary hypothyroidism in patients with $\mathrm{WBS}^{8-10)}$. In our patient, the thyroid gland morphology and volume were normal. The diagnosis of central hypothyroidism in our patient was based on the low free T4 and an inappropriately normal TSH on 2 occasions. A TRH stimulation test was not performed as it is considered to provide no additional information for routine patient management nowadays; this is occasionally used for research purposes to differentiate between secondary and tertiary hypothyroidism. Although the exact molecular mechanism of hypothyroidism in WBS remains uncertain, some initial reports suggested immaturity of the hypothalamic-pituitary-thyroid axis ${ }^{8)}$. An analysis of mutations of several candidate genes involved in pituitary and thyroid development in central hypothyroidism may elucidate the mechanism of central hypothyroidism in patients with $\mathrm{WBS}^{12)}$

Similar to central hypothyroidism, the adrenal insufficiency is also unreported in WBS till now. However, abnormalities of hypothalamic adrenal axis have been studied in adults with $W_{B S}{ }^{13)}$. The diurnal cortisol rhythm is altered with elevated cortisol late in the day ${ }^{13)}$. This cortisol awakening response in patients with WBS is consistent with the levels of stress of somatic complaints and social difficulties that they experience throughout the day ${ }^{13)}$. This infers that hypothalamic pituitary adrenal axis is normal in the majority of the patients with WBS and the adrenal gland is able to respond to stress ${ }^{13}$. Our patient showed secondary adrenal insufficiency which suggests that there is a need for screening for this abnormality in children with WBS. Anesthesia-related hemodynamic complications including sudden cardiac arrest are common in children with $\mathrm{WBS}^{14)}$. The usual presenting features in these patients at the time of arrest are hypotension and bradycardia that are refractory to the standard resuscitation protocols ${ }^{14}$. In many of these patients, there are no changes on pathological examination of the heart either suggesting that the cardiac anomaly was probably not directly linked to cardiac arrest ${ }^{14)}$. Although myocardial ischemia due to coronary perfusion abnormalities and use of anesthetic drugs such as suxamethonium and halothane may explain bradycardia and hypotension leading 
to cardiac arrest in some WBS patients, these complications have been noted in several patients unrelated to anesthesia or coronary artery hypoperfusion ${ }^{14-16)}$. It is notable that preoperative evaluation of hypothalamic pituitary adrenal axis is not carried out as a routine in patients with $\mathrm{WBS}^{14)}$. Bradycardia and hypotension are cardinal features of acute adrenal insufficiency ${ }^{17)}$. It is possible that some of these patients have an unrecognized adrenal insufficiency that gets precipitated during or after cardiac surgery.

In conclusion, we report a rare occurrence of central hypothyroidism and secondary adrenal insufficiency suggestive of hypopituitarism in a patient with WBS. This report indicates a need for studies for further characterization of endocrine dysfunction in children with WBS. In view of a wide array of endocrine abnormalities described in patients with WBS, a complete endocrine evaluation aimed at detection of abnormalities of hypothalamo-pituitary-thyroid and adrenal axes, and glucose, lipid and mineral metabolism should be undertaken in all these patients.

\section{Conflict of interest}

No potential conflict of interest relevant to this article was reported.

\section{References}

1. Francke U. Williams-Beuren syndrome: genes and mechanisms. Hum Mol Genet 1999;8:1947-54.

2. Strømme P, Bjørnstad PG, Ramstad K. Prevalence estimation of Williams syndrome. J Child Neurol 2002;17:269-71.

3. Morris CA, Demsey SA, Leonard CO, Dilts C, Blackburn BL. Natural history of Williams syndrome: physical characteristics. J Pediatr 1988;113:318-26.

4. Kim YM, Cho JH, Kang E, Kim GH, Seo EJ, Lee BH, et al. Endocrine dysfunctions in children with Williams-Beuren syndrome. Ann Pediatr Endocrinol Metab 2016;21:15-20.

5. Xekouki P, Fryssira H, Maniati-Christidi M, Amenta S, Karavitakis EM, Kanaka-Gantenbein C, et al. Growth hormone deficiency in a child with Williams-Beuren syndrome. The response to growth hormone therapy. J Pediatr Endocrinol Metab 2005;18:205-7.

6. Palacios-Verdú MG, Segura-Puimedon M, Borralleras C, Flores R, Del Campo M, Campuzano V, et al. Metabolic abnormalities in Williams-Beuren syndrome. J Med Genet 2015;52:248-55.

7. Stagi S, Manoni C, Scalini P, Chiarelli F, Verrotti A, Cecchi $\mathrm{C}$, et al. Bone mineral status and metabolism in patients with Williams-Beuren syndrome. Hormones (Athens) 2016;15:404-12.

8. Selicorni A, Fratoni A, Pavesi MA, Bottigelli M, Arnaboldi E, Milani D. Thyroid anomalies in Williams syndrome: investigation of 95 patients. Am J Med Genet A 2006;140: 1098-101.

9. Cambiaso P, Orazi C, Digilio MC, Loche S, Capolino R, Tozzi A, et al. Thyroid morphology and subclinical hypothyroidism in children and adolescents with Williams syndrome. J Pediatr 2007;150:62-5.

10. Stagi S, Manoni C, Salti R, Cecchi C, Chiarelli F. Thyroid hypoplasia as a cause of congenital hypothyroidism in Williams syndrome. Horm Res 2008;70:316-8.

11. Ciccone S, Fumarola A, Bigoni S, Bonifacci V, Marrella EM, Buldrini B, et al. Central Hypothyroidism and GH Deficiency in a Boy with Williams-Beuren Syndrome [abstract]. In: 54th Annual Meeting of the European Society for Paediatric Endocrinology (ESPE); 2015 Oct 1-3; Barcelona, Spain. Horm Res Paediatr 2015;84(suppl 1):1-622. Abstract No. P3-1172.

12. Dayal D, Prasad R. Congenital hypothyroidism: current perspectives. Res Rep Endocr Disord 2015;5:91-102.

13. Lense MD, Tomarken AJ, Dykens EM. Diurnal cortisol profile in Williams syndrome in novel and familiar settings. Am J Intellect Dev Disabil 2013;118:201-10.

14. Olsen M, Fahy CJ, Costi DA, Kelly AJ, Burgoyne LL. Anaesthesia-related haemodynamic complications in Williams syndrome patients: a review of one institution's experience. Anaesth Intensive Care 2014;42:619-24.

15. van Son JA, Edwards WD, Danielson GK. Pathology of coronary arteries, myocardium, and great arteries in supravalvular aortic stenosis. Report of five cases with implications for surgical treatment. J Thorac Cardiovasc Surg 1994;108:21-8.

16. Bird LM, Billman GF, Lacro RV, Spicer RL, Jariwala LK, Hoyme HE, et al. Sudden death in Williams syndrome: report of ten cases. J Pediatr 1996;129:926-31.

17. Serrano N, Jiménez JJ, Brouard MT, Málaga J, Mora ML. Acute adrenal insufficiency after cardiac surgery. Crit Care Med 2000;28:569-70. 